\title{
Black middle class township shoppers: a shopper typology
}

\author{
Nontuthuzelo Mashaba* and Melanie Wiese \\ Department of marketing management, University of Pretoria, Pretoria, South Africa
}

\begin{abstract}
Due to an increase in spending power amongst Black middle class, this growing segment has become a lucrative investment opportunity for many retailers in South Africa and most emerging markets. The purpose of this study is to segment township consumers according to their demographics, life stage, attitudes towards township shopping centres and Living Standards Measure, to understand shopping patterns of township consumers. A survey among Soweto Black middle class township respondents was conducted, and maximum likelihood factor analysis was used to identify attitudes towards township mall factors. The study revealed five factors namely: entertainment, convenience, mall essence, staff and mall basics, which were all consistent with previous studies, with the exception of staff and mall basics, which was revealed in this study. A Kmeans cluster analysis was then used to segment township shoppers according to their attitudes. Four shopper segments were discovered, namely: disappointed crusaders, upcoming loyals, social seekers and local loyals, which, despite investigating shopper attitudes in place of shopper behaviour alone, were similar to well-establish shopper typologies. Each segment was profiled according to demographic variables, attitudes as well as shopping patterns. Results therefore suggest that retailers and developers need to consider the unique needs and differences among Black middle class consumers when developing retail strategies as they reveal unique characteristics from typical shopper typologies. Given similarities in some emerging countries such as India, the findings of this study could be generalized to other middle class consumers from emerging markets. Similar shopper segments may arise, which may be consistent with previous shopper typology studies and new segments unique to emerging market middle class consumer may be unveiled.
\end{abstract}

Keywords: Black middle class, attitudes, shopping malls, townships, segmentation, South Africa

\section{Introduction}

Enticed by the billions of consumers and opportunities presented by emerging markets around the world, multinational corporations (MNC's) have spent the past two decades exploring the fast-growing emerging markets (Dawar \& Chattopadhyay, 2002, Miotto \& Parente, 2015). Given the emergence of the new middle class in these markets and the increase in purchasing power, emerging markets continue to be the focus of this century's discussion for marketers (Donaldson, Mehlomakhulu, Darkey Dyssel \& Siyongwana, 2013; Miotto \& Parente, 2015; Sheth, 2011). According to Karebuka, (in Donaldson, Mehlomakhulu, Darkey Dyssel \& Siyongwana, 2013), in Africa 
specifically, the economic growth is largely driven by the rapid growth of the Black middle class, whose income and spending power is increasing too. In South Africa, this middle class consumer is likely to be Black consumer, and a township dweller (Brooks, 2011; Donaldson, Mehlomakhulu, Darkey Dyssel \& Siyongwana, 2013; O’Donovan, 2011).

Post- apartheid (1994), South African townships have received a great deal of attention from the business sector as new business opportunities within this sector arose (Ligthelm, 2007; Strydom, 2011). Townships were seen as untapped new markets, resulting from being underdeveloped and underserved by the previous apartheid government (Ligthelm, 2007; Nkosi, 2011; Strydom, 2011). Particular focus has come from the retail sector, resulting in increased interest from retail chains investing in this untapped market, and an increased number of malls and shopping centres being built in townships and rural areas (Demacon, 2010; Ruhiiga, 2011).

South Africa has focussed research on understanding the size and growth of the informal sector, township markets, emergent and established middle class, and more recently the Black middle class (Media Release, 2004; Ruhiiga, 2011; Haferburg, 2012; Donaldson, Mehlomakhulu, Darkey Dyssel \& Siyongwana, 2013; Burger, Louw, de Oliveira Pegado \& van der Berg, 2015). Ligthelm (2003) investigated the opportunities for entrepreneurship and the sustainability of small business in townships given the rapidly changing environment. Media Release (2007) and Demacon (2010) looked at the impact of retail chains in townships on local business, and various authors looked at the success stories of large malls in townships, particularly Soweto (Prinsloo, 2008). Recent studies have highlighted the importance of the middle class segment and investigated who and what constitutes the middle class (Visagie and Posel, 2013), and looking specifically at the Black middle class' attitudes towards the township at large (Donaldson, Mehlomakhulu, Darkey, Dyssel and Siyongwana, 2013). In terms of consumer research, the focus has been on examining the spending power of low-tomiddle income rural and township dwellers and their changing shopping patterns given the increase in choice (Ligthelm, 2007; Ruhiiga, 2011, Burger, Louw, de Oliveira Pegado \& van der Berg, 2015). The UCT-Unilever Institute of Strategic Marketing has focused a lot of research on understanding Black consumers, investigating urban and rural areas, young and old consumers, as well as poor, aspiring and wealthy consumers, but only from a practitioner point of view, where the rigour methodology required for academic research are not clear (SAinfo, 2006a, 2006b, 2007, 2013). Recently, Burger, 
Louw, de Oliveira Pegado and van der Berg (2015) investigated the consumption patterns of the emerging and established South African Black middle class.

This study specifically looks at the Black middle class, as this segment differs from their White counterparts culturally, influencing their consumption preferences and choices (Burger, Louw, de Oliveira Pegado \& van der Berg, 2015; Donaldson, Mehlomakhulu, Darkey Dyssel \& Siyongwana, 2013; Kaus, 2013). This study answers the research question, how can marketers segment this important Black middle class segment in a way that will result in effective retailing and marketing practices. To answer this question, this study investigates the attitudes of the Black middle class towards the township shopping centres, which are largely targeted at them specifically, and develops a typology of Black middle class shoppers based on these attitudes as well as their shopping patterns. The focus of this study is township shopping centres, specifically in the largest township in South Africa, Soweto, in which a substantial portion of residents are classified as Black middle class (Donaldson, Mehlomakhulu, Darkey Dyssel \& Siyongwana, 2013).

The study contributes to the literature on the middle class segment, and specifically the emerging market consumers. The emerging middle class segment is of great interest as the segment is growing rapidly in South Africa, the rest of Africa and is emerging economies such as Brazil, China and India (Burger, Louw, de Oliveira Pegado \& van der Berg, 2015; Miotto \& Parente, 2015). Future retailing researchers, as well as researchers focusing on the middle class, and specifically emerging and Black middle class can benefit from this knowledge and build upon this research. Retailers interested in targeting this segment will be enlightened on what factors are important to consumers when forming attitudes towards shopping centres, and can focus on appropriate segments, and develop retailing strategies accordingly.

The following questions have guided this research: what are the attitudes of the Black middle class township consumer towards the shopping centres developed specifically for them? Which store types does the Black middle class frequent? The overall purpose of this study is segment the Black middle class township consumer based on demographic variables, attitudes towards shopping malls as well as shopping behaviour of Black middle class township consumers.

A key assumption is that the township shopper is also the consumer of goods and services acquired; therefore shopper and consumer are used synonymously in the study. 
In addition, shopping centres refer to small and large shopping malls and centres as well as strip malls.

\section{Literature Review}

Since 1994, the end of the Apartheid era, the emergence of the Black middle class has been of great importance as this group has grown rapidly annually since 1994 and now makes up over $50 \%$ of the South African middle income group (McGaffin \& Gavera, 2011). According to the UCT Unilever Institute of Strategic Marketing, in the eight year period from 2004 to 2012, the Black middle class more than doubled in size (SAinfo, 2013). Various authors have attempted to define the middle class segment in a South African context. According to Visagie (2013), the South African middle class can be define using income as consumers with a monthly household income of between R5 600 and R40 000 (\$452 - \$3 229) per month. The South African Advertising Research Foundation defines the middle class as consumers falling into the Living Standards Measure (LSM) $5-8$ category, where LSM is a multivariate segmentation tool that uses criteria such as degree of urbanisation, ownership of cars, major household utilities and assets (SAARF, 2012; Consumer Scope, 2011).

It is therefore clear that the SA middle class group is the largest segment, is fastgrowing and is deserving of marketers' attention. To be specific, the Black middle class warrants marketers' attention as this segment is what is driving the growth of this middle income segment, and are said to have more spending power than their White counterparts (African Development Bank, 2011; Burger, Louw, de Oliveira Pegado \& van der Berg, 2015). When looking at the Black middle class in South Africa, it is important to note that they are likely to be township dwellers, either living in a developed and affluent township such as Soweto in Johannesburg, or a developing township such as Langa in Cape Town (Brooks, 2011; O’Donovan, 2011). Although they may be financially capable of living in the suburbs, $53 \%$ of the Black middle class chooses to live in the township because of social and family ties (Demacon, 2010; McGaffin and Gavera 2011).

According to Boumphrey and Bevis (2013) it is important to note that what is effective in developed markets does not simply translate to emerging markets, such as South Africa. More importantly, consumer spending growth in emerging markets has outpaced that of developed countries every year since 2000 and is expected to continue to do so, thus making this a market of interest. Sithole (2011) argues that the middle to 
upper classes are the basis of economic activity that nations are built and thrive on. Thus for companies looking to invest in other countries, they first need to assess the purchasing power and understand the shopping behaviour of the middle- and upperclass, particularly the urban middle- and upper-class. A middle class income is an indicator of sufficient spending power to consume non-essential goods and for many companies this segment is considered to be their mainstream target consumer (Boumphrey \& Bevis, 2013).

In order for marketers and retailers to well serve these markets, it is important that marketers have a sufficient understanding of this market, and be careful not to treat them as one homogenous group (Kunene, 2011). Segmenting this market will allow for the retailer to know what this consumer is looking for, therefore allowing the retailer to satisfy this consumers' need which will ultimately lead to increased profits for retailers (Dunne \& Lusch, 2008).

\section{Township Black middle class residents and shoppers}

In South Africa, the term township refers to an urban area set aside for non-White people. According to Pettman (1913), townships and locations are synonymous, and in defining location, he refers to them as the "portion of land set apart by a municipality somewhere on the outskirts of the town, upon which natives are allowed, under certain regulations, to reside", where native people refers to Black, Coloured (mixed race) and Indian people. These portions of land although said to be urban residential areas for Black people were often underdeveloped (Ligthelm, 2007; Nkosi, 2011; SouthAfrica.info, 2006a). These townships are similar to the African American poor and urban ghettos.

Post-apartheid, townships have remained racially segregated, but many of the townships have seen substantial development and improvement in living standards (Huchzermeyer, 2011). In her article Mtongana (2008) stated that the face of townships was surely changing. These changes are largely driven by the rise of the Black middle class, who despite an increase in wealth, have chosen to stay in the townships (Demacon, 2010; Donaldson, Mehlomakhulu, Darkey \& Dyssel, 2013; SouthAfrica.info, 2006b). In 2008 Pam Golding, a leading real estate agency, for instance reported that they were selling a house worth R2.8 million (\$226 016) in 
Diepkloof, Soweto (SA Good News, 2008). This is an indication that township dwellers are not only low-to-middle income consumers, but more affluent with a substantial portion of the Black middle class consumers choosing to stay in townships (Donaldson, Mehlomakhulu, Darkey Dyssel \& Siyongwana, 2013; Mtongana, 2008).

Pre-apartheid township retailing has been limited to small convenience stores selling basic goods to relatively low income consumers (Ligthelm, 2007). If consumers needed more than what was offered in the township, they would have to shop at the main city centres or at shopping malls at the outskirts of townships (Ligthelm, 2007:1).

Post-1994, this picture has changed significantly. A particular focus has come from the retail sector, resulting in increased interest from retail chains investing in this untapped market, and an increased number of malls and shopping centres being built in townships and rural areas (Demacon, 2010; Ruhiiga, 2011). In 2006 Jabulani Mall in Soweto, became the first shopping mall to be opened in a South African township. Shortly after that (2007) Maponya Mall, also in Soweto, was opened and was to be the first mega regional mall in a township, with A-grade finishes, same tenant mix as a its urban area counterparts, offering an "all-inclusive entertainment centre with cultural exhibitions and activities designed to attract tourists" (Bruyn \& Freathy, 2011; Findley $\&$ Ogbu, 2011). In the past 12 years, over 85 shopping centres have been developed in South Africa, with a majority of these being developed in townships (McGaffin, 2011). Since the late 1990s the South African township market has become immensely important to retailers, with more than six malls located in Soweto alone (Ligthelm, 2007).

The retail environment in townships differs from the retail environment in urban areas. Post- 1994 marketers have come to understand that they need to cater to the new emerging consumer. For instance, catering to the new middle class consumer required companies to extend their product ranges to include products specific to Black consumers, as well as start offering credit in response to the shopping behaviour of the Black middle class (Bruyn \& Freathy, 2011).

Township consumers have reacted differently to the influx of malls and shopping centres in their community. In 2004 (pre-Maponya Mall), it was found that only an estimated $25 \%$ of retail expenditure was on local outlets (Ligthelm, 2007). Once the likes of Maponya Mall had been developed however, this changed. There was also a benefit to the more affluent township consumers who, initially were looking for a more upmarket experience, were now able to redirect their shopping expenditure to their local 
communities as a result of more upmarket shopping centres being available (Strydom, 2011).

In a study conducted by Urban Landmark (2011) they discovered that consumers decreased their expenditure out of the township, in favour of spending more locally and were now doing their main shopping in their shopping centres. Although consumers are gradually switching, residents in places like Soweto continue to make $74 \%$ of their retail purchases outside the township (Findley \& Ogbu, 2011). In his study, Strydom (2011) concluded that despite the emergence of township shopping centres, consumers will always have a need to shop outside of their townships, for reason such as variety and competitive prices, seeking shoppertainment which may not be available at their local shopping centres, or just the novelty of being a retailing environment out of their community. It is therefore imperative that local retailers and marketers get a better understanding of the Black middle class consumer in order to ensure that they are catering to all their shopping needs. This could be achieved through segmentation of this consumer, to investigate needs and behaviour according to subgroups.

\section{Segmentation}

In retailing, the demographic variables of age and gender are commonly used, in isolations, or often combined to form multi-demographic classifications such as life stages and lifestyles (Beane \& Ennis, Levy \& Weitz, 2004; 1987; Moschis, 1992) to differentiate consumers according to shopping behaviour. In addition, retailers, through the use of psychographic variables, can gain more insight into a market segment, particularly being able to identify the internal drivers of decision makers and therefore have a better understanding of that market segment (Reynolds \& Darden, 1972; Venkatesh, 2011).

A multivariate segmentation tool unique to South Africa is Living Standards Measurements (LSM) (SAARF, 2012). This tool, although not without its criticism, has been widely used by practitioners in South Africa and is in essence a measure of wealth, without looking at income (Consumer Scope, 2011). Consumers are classified into ten LSM categories, where 1 is considered a low standard of living and 10 is considered a high standard of living. Although LSM's are unique to South Africa, they are similar to the American Values, Attitudes and Lifestyle System (VALS) which classifies consumers into eight life groups, according to self-orientations and resources (Business Dictionary, 2012; Schiffman \& Kanuk, 2010). Researchers across different fields have 
used LSM's to segment individuals (De Kock, Van Heerden, Heinze, Dijksterhuis, \& Minnaar, 2001; Vermeulen, Kirsten, Doyer, \& Schönfeldt, 2005).

Yet another segmentation tool, the Life stages model, is a segmentation tool based on an individual or a family's development stages such as married with children or divorced and segments South Africans into nine life stages, similar to international life stages. (Du Plessis \& Rousseau, 2007).

From a practical research perspective, the UCT-Unilever Institute of Strategic Marketing segmented the Black middle class based on variables such as aspirations, media consumption and the origins and drivers of this economic, where they coined the term "Black Diamonds" which was used to describe this consumer (Cohen, 2011; Goyal, 2010; SouthAfrica.info, 2007).

The South African Research Foundation (SAARF) has also conducted segmentation research examining the Black middle class. Research focussed on a combination of demographic, psychographic and life stages variables and segmented the Black middle class into four segments accordingly. The segments are: established individuals, young families, start me ups and mzansi youth (Du Plessis \& Rousseau, 2007), where the established are older and wealthy and majority are employed, the young families are young mostly single parents with young children, the start me ups are young, ambitious, starting their careers, single and likely to be township dwellers, and the mzansi youth are single students living with their parents, ambitious and highly township oriented (Du Plessis \& Rousseau, 2007).

Marketers have used a combination of uni-variate and multi-variate segmentation models, either fitting the data into predetermined or a priori segments, such as age, race, gender LSM, or discovering natural clusters from similarities found within the data (Moschis, 1992, Wind, 1978). Although throughout the literature, various segmentation techniques have been used to segment consumers and South African consumers specifically, none have specifically aimed at better understanding the South African Black middle income consumer from a shopping perspective, looking at shopper typologies as research has found that this consumer group is different to their White counterparts, and as a group is not homogenous, particularly with regards to shopping and consumption patterns (Donaldson, Mehlomakhulu, Darkey Dyssel \& Siyongwana, 2013). 


\section{Attitudes and shopper typologies}

Attitudes have been used extensively in segmentation studies and continue to be key to understanding consumer and shopping behaviour, and the development of successful marketing and retailing strategies (Shim \& Easlick, 1998). For decades, researchers have also spend a considerable amount of time investigating shopping centre attributes, frequency of shopping, as well as motivations for and attitudes towards shopping, and relating these variables to shopper profiles and typologies (Broadbridge \& Calderwood, 2002; El-Aldy, 2007; Kuruvill \& Joshi, 2010; Lesser \& Hughes, 1986; 2010; Mortimer, 2013; Shim \& Eastlick, 1998).

Lesser and Hugh (1986) analysed various typology studies, and concluded that in general, shoppers fall into 21 typologies such as active shoppers, service shoppers and price shoppers. Many authors have built upon this research, either confirming that their typologies fit into these 21 typologies, or discovering that their studies have revealed a new typology (Breazeale \& Lueg, 2010; Mortimer, 2013; Shim \& Eastlick, 1998). Kuruvill and Joshi (2010) used a 12 item scale in attempt to segment mall shoppers according to their attitudes towards mall attributes. They discovered segments similar to Lesser and Hugh's (1986) typologies, namely aspirational shoppers, price-conscious shoppers, traditional shoppers, disinterested shoppers and students shoppers. Khare (2011) investigated the age and gender differences in attitudes towards shopping malls of small town Indian shoppers. Mortimer (2013) segmented male and female grocery shoppers according to store and product attribute evaluations while Jayasankaraprasad and Kathyayani (2014) investigated subgroups based on store format choice and loyalty towards the store.

El-Adly (2007) developed a scale measuring shopping centre attractiveness and used shoppers' evaluations of these attributes to segment them. El-Adly (2007) discovered six mall attractiveness factors namely: comfort, entertainment, diversity, mall essence, convenience, and luxury. Combining these attractiveness factors with demographic variables as well as shopping behaviour, El-Adly (2007) then segmented shoppers into three typologies, using cluster analysis. These segments were the relaxed shoppers, the demanding shoppers, and the pragmatic shoppers. Reynolds, Ganesh, and Luckett (2002) also used mall attributes to segment shoppers into five segments while Sit, Merrilees, and Birch (2003) used mall image attributes to segment shoppers. Unfortunately only a few segments appear consistently across the studies-namely economic, social, and apathetic shoppers (Farrag, Sayed and Belk, 2010). 
Numerous researchers have investigated the relationships between attitudes towards malls and shopping related variable, and how this in turn relates to shopping behaviour as well as the motivations and decision on where and how shoppers spend their money (Cai \& Shannon, 2011; Morschett, Swoboda \& Foscht, 2005; Shim \& Eastlick, 1998).

Understanding how consumers make the decisions to spend their money, where they choose to shop, what they choose to shop for remains of utmost importance to marketers and retailers specifically. The influx of township shopping centres targeted at the Black middle class consumer living in these townships warrants research aimed at understanding this target market's attitudes towards these shopping centres specifically.

\section{Methodology}

The sample was drawn from Black South Africans above the age of 18, currently living in Soweto, irrespective of gender or income. The research comprised of two phases, a qualitative phase and a quantitative phase. Phase one was a qualitative design, consisting of focus groups and served as input for phase two, the quantitative design. The qualitative stage was exploratory in nature and focus groups were used as the aim of a focus group is to spark interactive spontaneous discussions.

A review of the literature, as well as the focus group interviews amongst five Black middle class township consumers were conducted aimed at testing the "shopping centre attractiveness" scale used by El-Aldy (2007) to ensure that items measuring "attitudes toward the township shopping centre" were relevant for a South African township context. From this, the attribute 'service delivery' of EL-Aldy emerged as too general and were divided into three items "the staff is helpful", "the staff is friendly" and "the service is very fast." It was also important to add "there is enough public transport to and from the shopping centre" as the majority of black South Africans depend on public transport. According to the South African National Taxi Council (Santaco), taxis alone transport approximately 15 million commuters daily and this consists of 60 to $70 \%$ of the commuting public and workforce (Oxford, Mail and Gaurdian Newspaper, 2013). The attribute "popularity of the mall" was reworded for respondent's understanding. In addition, the attributes "comfortable interior design", "mall width" and "external appearance of the mall" were condensed and reworded as respondents found them to be unclear. Lastly, items such as "availability of international store branches" and "loyalty programmes" were removed as these shopping centre attributes do not exist in these 
township shopping centre context. In the end, the final scale was a reduced version of El-Aldy's scale with 21 items instead of 25.

Once the pre-test was completed, the final research instrument was compiled and distributed. Respondents were given a questionnaire which consisted of demographic questions and LSM multi-response questions taken directly from SAARF. A 5-point Likert scale (where " 1 " indicated "strongly disagree" and "5" indicated "strongly agree") measuring attitudes towards local shopping centres was adapted from El-Adly (2007) as previously explained, including the focus groups conducted. Shopping patterns was measured using a self-developed shopping frequency scale, measured on a 7-point Likert scale (where "1" indicated "never visit store" and "7" indicated "visit store daily").

The data was collected using non-probability convenience sampling. Caution was taken when collecting data to ensure that the sample was diverse with regards to gender, age and location within Soweto to increase generalizability of the findings. Handdelivered questionnaires were distributed at various township hot spots such as car washes, busy street corners, community programmes and churches in and around Soweto.

A total of 800 questionnaires were distributed, and a total of 230 responses were deemed useable. Questionnaires excluded from the study ranged from, respondents not living in Soweto, incomplete questionnaires and questionnaires completed incorrectly. Although this resulted in a low response rate (28.8\%), studies have used anything from 150 respondents to segment consumers using various segmentation tools such as $\mathrm{K}$ means cluster analysis (Broadridge and Claderwood 2002; Kuruvilla and Joshi 2010) (Stone, 1954) to 2700 respondents (Kuruvill \& Joshi, 2010).

\section{Descriptive statistics}

Table 1 below is a summary of the all the descriptive statistics. The entire sample constituted of Black middle class respondents living in various locations within Soweto. Of this, $62.1 \%$ were female and $36.3 \%$ male. The majority of the sample $(58.0 \%)$ was younger than 34 years, with the age group $18-24$ accounting for $26.3 \%$ and $25-34$ accounting for $31.7 \%$ of the total sample size. Age group 35 - 44 accounted for $18.3 \%$, 45 - 54 for $10.0 \%$ and $55+$ accounting for $8.8 \%$ of the total sample; $5.0 \%$ of respondents did not indicate their age. 
Table 1 Summary of descriptive statistic

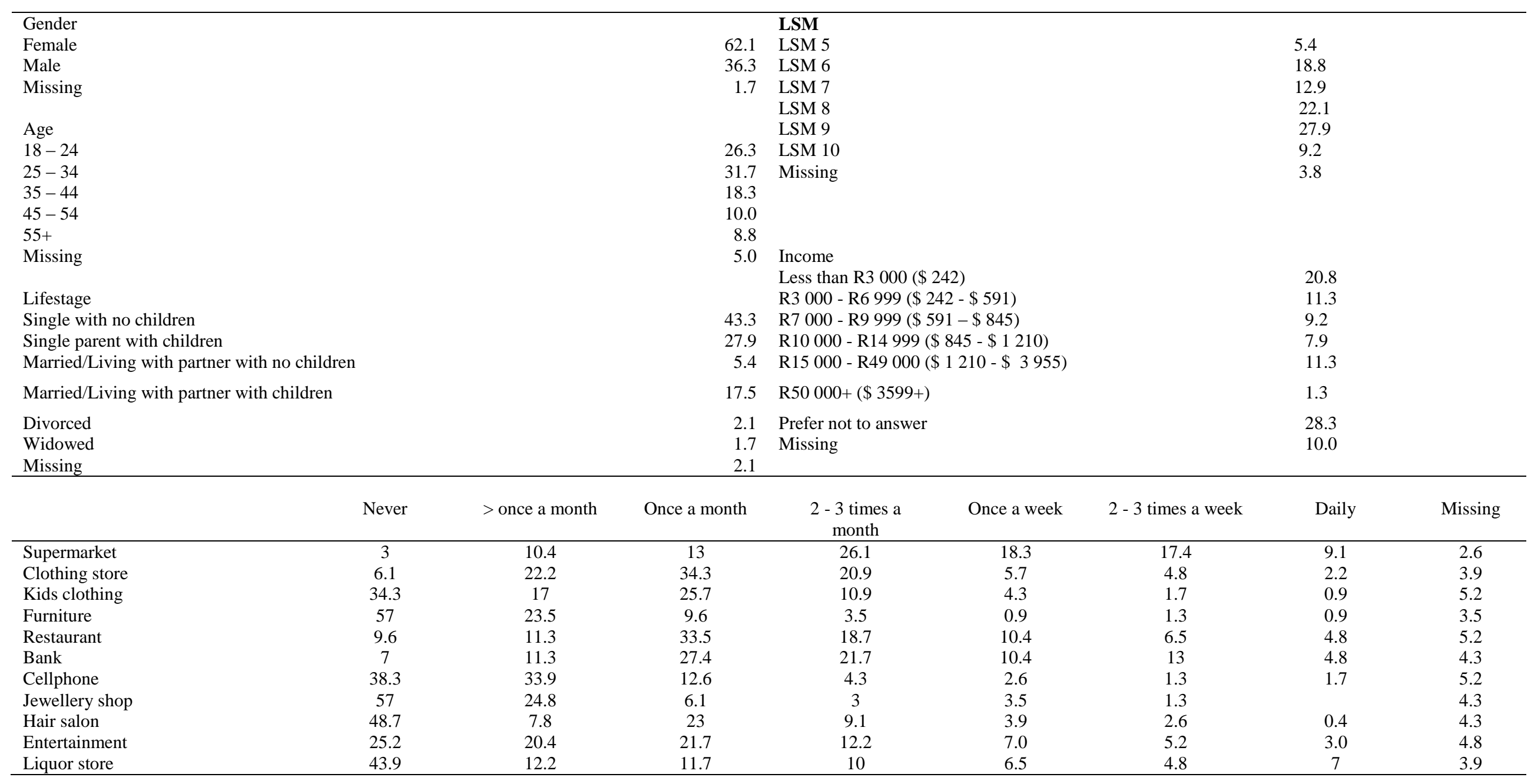


With regards to life stages, $2.1 \%$ of the sample did not indicate their life stage. Majority of the sample (43.3\%) was single with no children. $27.9 \%$ were single parents, 5.4\% married with no children, $17.5 \%$ married with children, $2.1 \%$ divorced and $1.7 \%$ widowed. Considering the fact that the majority of the sample was younger than 34 $(58.0 \%)$ it comes as no surprise that the largest life stage group consists of single individuals with no children (43.3\%). What was not investigated was whether this category was living on their own and independent.

Despite the availability of a "prefer not to answer" option, $10.0 \%$ of the sample did not answer the question where they had to indicate their monthly income. Instead they left this section blank. In addition, $28.3 \%$ of the sample selected "prefer not to answer". This result could be an indication that respondents are not comfortable releasing this information. Despite respondents' unwillingness to share their income information, $20.8 \%$ of respondents reported that they earn less than R3 000 (\$242), 28.4\% earned between R3 000 (\$242) and R14 999 (\$1 210), 11.3\% reported that they earn between $\mathrm{R} 15000$ (\$1 210) and R49 000 (\$3 955) and 1.3\% reported that they earned above R50 000 (\$3 955).

A total of $18.8 \%$ of respondents fell into the LSM 6 category. A substantial $59.9 \%$ of the sample was in LSM 8 and above, with $27.8 \%$ in LSM 9 and 9.5\% in LSM 10 while $3.5 \%$ of the sample did not complete this question.

\section{Attitudes towards township shopping centres}

Respondents generally had a positive attitude to their local township shopping centres, with means scores greater than three which represented neutral. Respondents agreed and strongly agreed that the shopping centres were easy to get to $(\mathrm{M}=4.267, \mathrm{SD}=0.964)$, that there was enough parking available $(\mathrm{M}=4.035, \mathrm{SD}=1.049)$, as well as sufficient public transport to and from the mall $(\mathrm{M}=4.053, \mathrm{SD}=1.101)$, with each of these attributes having a mean score above 4 (agree). The lowest mean score was for the speed of the service, with $40.4 \%$ of respondents rating this attribute at 3 (neutral), and $26.1 \%$ rating it lower than 3 (disagree and strongly disagree). Similarly, 56.5\% of the respondents scored a 3 and below to "the staff are very helpful", 58.3\% scored a 3 and below to "the staff are friendly" and $65.2 \%$ of respondents scored a 3 and below to "the prices are attractive". 


\section{Shopping frequency}

The most frequently visited store type in township shopping centres are supermarkets, with $44.8 \%$ of all respondents visiting supermarkets at least once a week. The least visited stores are furniture stores as well as jewellery stores, with $57.0 \%$ of respondents indicating that they never visit either of these store types. This could be due to the nature of the products. Interestingly, $67.3 \%$ of respondents visited the entertainment area once a month or less often, despite the increase in shoppertainment in the retailing industry.

\section{Results}

\section{Attitudes towards township shopping centres}

Maximum likelihood factor analysis with promax rotation was used in order to extract factors from the 21 items used to measure attitudes towards the township shopping malls.

As indicated in Table 2, the first factor had seven items loading onto it $(14.0 \%$ variance explained), with items relating to entertainment for shoppers and children, variety of stores and restaurants. It was therefore named "entertainment" (Chronbach's alpha of 0.827). This factor was similar to the factor discovered by El-Adly (2007). The second factor was labelled "mall essence" as it contained nine items relating to quality, variety of products, the cleanliness of the mall, and the service speed. This factor had a Chronbach's alpha of 0.846 and explained $21.0 \%$ of the variance. The third factor had items such as the ease of access to the mall, parking availability and public transport. This factor was similar to El-Adly's (2007) factor and was therefore labelled “convenience" (Chronbach's alpha of $0.711,5.3 \%$ variance explained).

The fourth factor only had two items loading into it, an Eigen value of below one and only explained $3.2 \%$ of the variance. Although this factor should have consequently been excluded from the study, it was retained as the items loading onto it were unique to this scale, and were similar in what they measure. The two items loading onto this factor were related to staff friendliness and staff helpfulness. The factor was therefore labelled "staff" and had an Eigen value of 0.665. The last factor was different from any factor discovered by El-Adly (2007). It had an Eigen value below one (0.668), and explained $3.0 \%$ of the variance. 
Table 2. Factor analysis: Attitudes towards township shopping centres.

\begin{tabular}{|c|c|c|}
\hline Factors & Attitudes toward township shopping centre & Factor loading \\
\hline \multicolumn{3}{|c|}{ Entertainment } \\
\hline & The shopping mall offers entertainment for children & .715 \\
\hline & The shopping mall offers me entertainment & .655 \\
\hline & There is a variety of shops & .508 \\
\hline & The shops in the shopping mall sell stylish clothes & .358 \\
\hline & My shopping mall offers many product promotions & .495 \\
\hline & The shopping centre has beautiful décor & .461 \\
\hline & There are nice eating places and restaurants & .312 \\
\hline & Eigen value $=2.939$ & $\alpha=.827$ \\
\hline \multicolumn{3}{|c|}{ Mall essence } \\
\hline & The quality of the products is good & .646 \\
\hline & The local shopping mall is clean and tidy & 610 \\
\hline & There is a wide range of products & .570 \\
\hline & The staff is helpful & .375 \\
\hline & The shops in the shopping all sell stylish clothes & .318 \\
\hline & I can get everything I need in the shopping mall & .441 \\
\hline & There are nice eating places and restaurants & .331 \\
\hline & The service is very fast & .353 \\
\hline & There is a variety of shops & .457 \\
\hline & Eigen value $=4.403$ & $\alpha=.846$ \\
\hline \multicolumn{3}{|c|}{ Convenience } \\
\hline & There is always public transport available to me & .826 \\
\hline & The shopping centre is easy to get to & .707 \\
\hline & The local shopping centre has enough parking & .529 \\
\hline & It is always full and busy & .333 \\
\hline & Eigen value $=1.104$ & $\alpha=.711$ \\
\hline \multicolumn{3}{|l|}{ Staff } \\
\hline & The staff is friendly & 1.022 \\
\hline & The staff is helpful & .436 \\
\hline & Eigen value $=0.665$ & $\alpha=.755$ \\
\hline \multicolumn{3}{|c|}{ Mall basics } \\
\hline & B18: The opening hours are long & 638 \\
\hline & B20: The service is very fast & .491 \\
\hline & B10: The prices are attractive & .371 \\
\hline & B23: The shopping centre has beautiful décor & .358 \\
\hline & Eigen value $=0.668$ & $\alpha=.675$ \\
\hline
\end{tabular}

It contained items relating to attractiveness of prices, operating hours, speed of service, and the mall décor. This item was therefore labelled "mall basics" as it pertained to very basic requirements of a mall. El-Adly's (2007) scales had two other factors namely "luxury" and "diversity" but the items loading to these factors loaded on other factors in this specific scale. 


\section{Shopper segments}

K-means cluster analysis was used to segment shoppers according to their attitudes towards the local township shopping centres. The number of segments was determined by using the rule of thumb, $\sqrt{n} / 2$ which equalled to eleven clusters. The cluster analysis was then run, but the results generated three clusters with less than 10 cases in them. Kmeans was then re-run until four clusters with at least 10 cases in each cluster emerged. All cases were assigned to a cluster. The number of cases in each cluster was determined as follows: "Cluster $1=13$ members, i.e. 5.7\%"; "Cluster $2=35$ shoppers, i.e. $15.2 \%$ "; "Cluster $3=71$ shoppers, i.e. $30.9 \%$ "; "Cluster $4=111$ shoppers, $48.3 \% "$ ".

The ANOVA revealed that all variables showed significant differences between clusters at a significance level less than 0.05, with the exception of gender. From the demographic variables, LSM, Life stages, Age, Income and Residence were all significant as they all had p-values less than 0.05. Looking at the five factors measuring attitudes towards the shopping mall, all were significant, with p-values less than 0.05. Lastly, all shopping frequency items were significant except for gender, p-value $=0.10$ ).

\section{Segment 1: disappointed crusaders}

Segment 1 has the smallest number of shoppers in it (5.7\% of respondents). This segment is relatively young, with $69.2 \%$ of the segment being in the 25 - 34 years age group. The respondents are single with or without children (76.9\%), lie in the lowest middle class LSM category (58.3\% in LSM 6) and of the $53.8 \%$ of respondents who indicated their income, all of them have an income of less than R3 000 (\$242). This segment has the most negative attitudes towards township shopping centres across all factors, feeling that the township shopping centres do not offer convenience, particularly related to availability of public transport, that the shopping centres do not have the mall basics such as attractive prices and fast service. Interestingly, despite their negative attitudes towards the township shopping centres, this segment was the most frequent shoppers, visiting the supermarkets, banks, entertainment areas and liquor store at least once a week, and visiting the rest of the store types at least $2-3$ times a month.

\section{Segment 2: upcoming locals}

Segment 2 is constitutes $15.2 \% \%$ of total respondents. This segment is young, with $37.1 \%$ of respondents falling in the age group $18-24$ years, and $42.9 \%$ falling into age group $25-34$ years. This group is largely single with no children (42.9\%), or single 
with children (22.9\%) and are in the highest LSM groups, with $80.0 \%$ falling into LSMs 8 and above. Monthly income is scattered across all income brackets, with $34.3 \%$ of the segment preferring not to disclose their income, and $20.0 \%$ indicating that they earn an income of R15 $000(\$ 1,210)$ and above per month This segment overall has a positive attitude towards township shopping centres. They have a positive attitude towards the mall essence, particularly believing that the shopping centres offer quality products and are clean and tidy. This segment also agrees that the shopping centres are convenient, particularly with regards to accessing the shopping centres and availability of parking. This segment visits most store formats regularly, and specifically visits the supermarket, banks, restaurants and the entertainment area at least $2-3$ times a month.

\section{Segment 3: social seekers}

Segment 3 is the second largest segment, with $30.9 \%$ of respondents falling into this segment. This group is the youngest of all segments with $58.8 \%$ of the segment being between the ages of 18 and 24 years, and $30.9 \%$ being between the ages of 25 and 34 years. This group is unmarried, and majority single with no children (78.9\%).This segment is scattered with regards to LSM, however $56.4 \%$ of the segment lies in the LSM 8 category and higher. It is interesting to note however that despite the high LSMs, 38.0\% of this segment earns an income of R6 999 (\$565) or less, and a further $38.0 \%$ of the segment preferring not to disclose their income. This segment also has a positive attitude towards township malls, believing that the shopping centres offer convenience, particularly with regards to their accessibility and the availability of public transport to and from the shopping centre. The segment did however disagree that the service they get from employees believing that the staff is not helpful and friendly, in comparison to the other segments. Although this segment were occasional users of the shopping centres, visiting most store types once a month on average, they frequent social/entertainment stores such as restaurants, entertainment areas and liquor stores the most often (at least $2-3$ times a month).

\section{Segment 4: local loyals}

This segment represents $48.3 \%$ of the total sample and is the oldest of the segments with $36.0 \%$ of the segment being 45 years old above, and $29.5 \%$ being in the age group $35-44$ years. The majority of respondents are single/married/living with partner with children $(72.5 \%)$ and lie in the high LSM categories, with $65.2 \%$ being in the LSM 8 category and higher. This segment also has the highest income of all segments with 
$55.3 \%$ of the segment earning R10 000 (\$807) and above and more specifically $28.4 \%$ earning between R15000 (\$1 210) - R49 999 (\$4 036). This segment is the most positive about the township shopping centres, agreeing that the shopping centres are convenient, have the mall basics and essence, and offer great entertainment. Despite their positive attitudes, this segment frequents the various stores the least, indicating that they visit the supermarket $2-3$ times a month, but all other store times once a month or less. Table 3 below summarizes the four segments according to descriptive variables, illustrating the percentage of respondents in each category, as well as the significance of the differences between clusters.

\section{Shopping frequency}

The most frequently visited store type in township shopping centres are supermarkets, regardless of whether residents had a positive attitude towards the shopping centres or not. This is for example consistent with other emerging middle classes such as India where the majority of the consumption expenditure is on food (Mukherjee \& Satija, 2012).

\section{Discussion}

Despite the emergent and established Black middle class segments' increase in purchasing power, this segment continues to live in the township and happily make use of the local shopping centres for multiple purposes.

\section{Attitudes towards township shopping centre}

With regards to the attitudes towards township shopping scale, a five factor scale was revealed where each factor was considered to be reliable. The factors were entertainment, convenience, mall essence, staff and mall basics. The first three factors were similar to factors discovered by El-Adly (2007). The two remaining factors, "staff" and "mall basics", where unique to this adapted scale "Staff" contained items which were not measured in El-Adly's (2007) study. "Mall basics" however contained items previously measured in El-Adly's (2007) scale, but did not seem to load according to those factors. This could be an indication that the Black middle class respondents may view and rate these items differently.

Soweto Black middle class consumers generally have a positive attitude towards their local shopping centres, believing that they offer convenience; have the mall basics and 
essence in order and offer good entertainment. Retailers need to ensure that as retail property in townships increases that developers pay attention to attributes such as parking, easy access to the shopping centres as well as the availability of public transport to and from the shopping centres. This is particularly important given the substantial dependence on public transport amongst Black South Africans (Oxford, Mail and Guardian Newspaper, 2013). The Black middle class consumers did however feel that the staff friendliness and helpfulness was lacking. Shopping centre and specific store management in existing Soweto shopping centres therefore need to pay careful attention to customer service delivery and staff training, especially given the increase in competition as more township shopping centres are being developed.

Retail property developers therefore need to ensure that a fully functioning and well-stocked supermarket is anchor to any new shopping centres to be developed. Stores such as furniture and jewellery stores were least visited. This is consistent with data showing that a number of stores are closing their doors (Sibanyoni, 2012), and could be due to the nature of the products as they are generally infrequently purchased products. Retailers need to pay careful consideration to tenant mix, ensuring they cater to the Black middle class market's needs within townships accurately and profitably.

\section{Shopper segments}

This study revealed four shopper segments, "disappointed crusaders", "upcoming locals", "social seekers" and "local loyals" revealing differences in demographic variables, attitudes towards township shopping centres as well as shopping frequency. These segments are:

"Disappointed crusaders" is a young and negative segment and has the least income and lowest LSM levels. Lustig, Lopez-Calva and Ortiz-Juarez (2013) examined the rising middle class in Central and Latin America, observing that households located in the bottom of the middle class remains vulnerable to falling back into poverty. This might also hold true for the 'disappointed crusader' and explain why this segment is very conscious of prices. It is important for companies to engaging with this segment at an early stage in order to reap long-term rewards. An effective pricing strategy is needed to attract these bottom-of-the-middle class shoppers with affordable choices, gain their trust, and then eventually as they move upwards in the middle class, target them with more costly, value-added products and services. 
Table 3. Clusters: descriptive variables and attitudes towards township shopping centres.

\begin{tabular}{|c|c|c|c|c|c|c|}
\hline Variables & $\begin{array}{l}\text { Segment } 1 \\
\text { Disappointe } \\
\text { d crusaders } \\
\%\end{array}$ & $\begin{array}{l}\text { Segment } 2 \\
\text { Upcoming } \\
\text { loyals } \\
\%\end{array}$ & $\begin{array}{l}\text { Segment } 3 \\
\text { Social } \\
\text { seekers } \\
\%\end{array}$ & $\begin{array}{l}\text { Segment } 4 \\
\text { Local } \\
\text { loyals } \\
\%\end{array}$ & $X^{2 *}$ & Sig.** \\
\hline Age & & & & & 40.938 & .000 \\
\hline $18-24$ & 15.4 & 37.1 & 56.3 & 5.7 & & \\
\hline $25-34$ & 69.2 & 42.9 & 29.6 & 26.7 & & \\
\hline $35-44$ & 15.4 & 8.6 & 8.5 & 29.5 & & \\
\hline $45-54$ & - & 8.6 & 1.4 & 19.0 & & \\
\hline $55+$ & - & 97.1 & - & 19.0 & & \\
\hline Life stage & & & & & 32.120 & .000 \\
\hline Single with no children & 60.0 & 42.9 & 78.9 & 19.8 & & \\
\hline $\begin{array}{l}\text { Single parent with } \\
\text { children }\end{array}$ & 30.0 & 22.9 & 21.1 & 35.8 & & \\
\hline $\begin{array}{l}\text { Married with no } \\
\text { children }\end{array}$ & - & 11.4 & - & 7.5 & & \\
\hline Married with children & 10.0 & 20.0 & - & 29.2 & & \\
\hline Divorced & - & 2.9 & - & 3.8 & & \\
\hline Widowed & - & - & - & 3.8 & & \\
\hline$L S M$ & & & & & 13.129 & .004 \\
\hline $0-5$ & 7.7 & - & 10.8 & 4.6 & & \\
\hline 6 & 58.3 & 14.3 & 22.5 & 13.2 & & \\
\hline 7 & 15.4 & 5.8 & 9.2 & 17.0 & & \\
\hline 8 & 7.7 & 31.4 & 21.2 & 23.6 & & \\
\hline 9 & 7.7 & 37.1 & 25.4 & 30.2 & & \\
\hline 10 & - & 11.5 & 8.4 & 11.4 & & \\
\hline Income & & & & & 10.712 & .013 \\
\hline $\begin{array}{l}\text { Less than } \quad \text { R3 } 000 \\
(\$ 284)\end{array}$ & 46.2 & 14.3 & 38.0 & 8.1 & & \\
\hline $\begin{array}{l}\text { R3 } 000(\$ 284)-\text { R6 } 999 \\
(\$ 663)\end{array}$ & 7.7 & 8.6 & 18.3 & 9.0 & & \\
\hline $\begin{array}{l}\text { R7 } 000 \text { (\$663)- R9 } 999 \\
(\$ 947)\end{array}$ & - & 17.1 & 4.2 & 9.9 & & \\
\hline 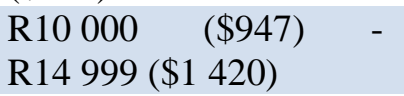 & - & 8.6 & 1.4 & 14.4 & & \\
\hline $\begin{array}{l}\text { R15 } 000 \quad(\$ 1420) \\
R 49000(\$ 4735)\end{array}$ & - & 17.1 & - & 17.1 & & \\
\hline $\mathrm{R} 50000(\$ 4735)+$ & - & 2.9 & - & 1.8 & & \\
\hline Prefer not to answer & 46.1 & 31.4 & 38.0 & 39.6 & & \\
\hline \multicolumn{7}{|l|}{ Attitudes (mean) } \\
\hline Entertainment & 2.5 & 3.6 & 3.5 & 3.4 & 11.898 & .008 \\
\hline Convenience & 2.7 & 4.0 & 4.1 & 4.1 & 17.534 & .001 \\
\hline Mall essence & 2.8 & 3.6 & 3.5 & 3.7 & 13.594 & .004 \\
\hline Mall basics & 2.4 & 3.6 & 3.3 & 3.4 & 15.458 & .001 \\
\hline
\end{tabular}


Despite this negative attitude, they still frequent the shopping centres across all store types on a weekly basis. This segment is unique to this study and warrants further investigation to understand why the segments is most disgruntled by the local shopping centres, and most importantly, how retailers can better their shopping experience. Given the high unemployment rate in South Africa amongst the youth, it would be interesting to investigate employment level of these respondents as this may reveal an added dimension not considered in this study.

The "upcoming loyals" are young and single or start-me-up families who, unlike the social seekers, earn an income. They are less distinct in terms of income levels as the income levels are scattered across the group. This could be because most of they are young professionals. Ad a segment, they are similar to Lesser and Hugh's "transitional shoppers". Shoppers that belong to this group are positive about the shopping centres in Soweto and are regular shoppers, visiting the stores within the shopping centres once a month. They are happy with the local shopping centres and describe them as being clean and tidy, with good product quality and overall offerings. As they become more established and form shopping, retailers need to journey with them and tailor towards their growing and changing needs as they move into different life-stages and possibly have higher spending patterns. "Social seekers" is the youngest group with a low income yet are in the high LSM groups. This segment is similar to previous discovered segments and have been name "student shoppers" (Kuruvalli \& Joshi, 2010) and "social butterflies" (Breazeale \& Lueg, 2010) as they are young and use the shopping centres for entertainment in an addition to shopping. This is also an important segment as Boumphrey and Bevis (2013) reported that younger middle class shoppers in emerging markets are leaping ahead of their elders. "Social seekers" could be students living at home with affluent parents, making them similar to the "mzansi youth" discovered by the SAARF (Du Plessis \& Rousseau, 2007). They are positive and use the township shopping centres largely for social reasons. These social seekers are occasional users of the shopping centres across other non-social store types. "Social seekers" will embrace variety and novelty of products and brands. Boumphrey and Bevis (2013) suggest that younger middle consumers are more likely to make "spur of the moment" purchases and this (variety, novelty and impulsiveness) could be the basis of a marketing strategy aimed at them.

Despite having the highest income levels and LSM classification, the "Local loyals" continues to live in townships, as opposed to relocate to more urban suburbs. This 
segment is very similar to Lesser and Hugh's (1986) "service shopper" as well as Kuruvilla and Joshi's (2010) “traditional shopper" segment. Studies have revealed various reasons for this, such as the need to be closer to family and social ties (Donaldson, Mehlomakhulu, Darkey Dyssel \& Siyongwana, 2013). This segment is similar to the SAARF's "established" segment, who tend to be older, and wealthy (Du Plessis \& Rousseau, 2007). This family oriented segment portrays what various studies have classified as the affluent township Black middle income consumer enjoying a more aspirational lifestyle. Although they are happy with the convenient and basic offerings of the local township shopping centres it important for marketers and shopping centre managers to not only market their products and services but also an associated lifestyle. They do not visit the shopping centres daily, but use them often enough to be considered frequent users.

\section{Conclusions, recommendations and limitations}

Township residents have a positive attitude towards their local shopping centres, and appear to be using these shopping centres for basic shopping needs such as grocery shopping. These shoppers agree that the shopping centres offer a great variety of shops but do not appear to be patronising these shops on a monthly basis. Retailers may therefore need to better understand the specific need of the Black middle class consumer, to ensure they have a relevant and profitable tenant mix.

Retailers in general need to ensure that the staff is well trained to be helpful and friendly, in order to enhance the service levels and overall retail experience for the black middle class, who have the option of shopping in more affluent shopping centres in predominantly White residential areas. Developers, regardless of what the shopper segment is, need to ensure that the shopping centres are conveniently located with enough parking and public transport available, given the great dependence on public transport amongst Black consumers.

Retailers targeting young consumers need to first ensure that these malls offer entertainment and social platforms such as restaurants, entertainment areas, liquor stores as well as stylish clothing stores and variety in terms of the tenant mix. They also need to ensure that the shopping centres are easily accessible regardless of whether respondents have cars or use public transport.

Retailers targeting older shoppers and families specifically also need to ensure that the mall basics are in order, such as extended operating hours, attractive prices and good 
quality products. The shopping centres need to be conveniently located, offering enough parking. Retailers need not extensively cater for entertainment as this shopper segment is not seeking entertainment from township shopping malls.

This research was the first to segment Black middle class consumers according to attitudes towards township shopping centres.

This study revealed a new segment, namely "disappointed crusaders", who despite the rise of the middle class, seem to be despondent and may not be seeing the positive changes in the economy. It would be interesting to investigate the reasons for this negativity, and investigate whether other emerging markets have despondent consumers with similar characteristics. It would also be interesting to test relationships between the variables to see if a shopping behaviour predictive model could be developed for a South African market, given the growth in the retail sector not only in the townships but in South Africa in general.

Given similarities in some emergent countries such as India, the findings of this study could be generalized to other middle class consumers from emerging markets. Similar shopper segments may arise, which may be consistent with previous shopper typology studies and new segments unique to emerging market middle class consumer may be unveiled. Both countries are pluralistic, multilingual, multi-ethnic and multireligious democratic societies characterised by poverty and inequality, but most importantly a tremendous growth in the middle - to upper class (Sithole, 2011). Furthermore, there is hardly any research in India which analyses their needs, consumption or shopping patterns and attitudes of the middle class and the challenge is further complicated by the fact that the Indian middle class is not a homogenous group (Mukherjee \& Satija, 2012). It is suggested that future research investigate if the same shopper segments transpires in other emerging countries middle classes.

\section{Disclosure statement}

No potential conflict of interest was reported by the authors.

\section{References}

African Development Bank. 2011. The middle of the pyramid: dynamics of the middle class in Africa. African Development Bank. http://www.afdb.org/fileadmin/uploads/afdb/Documents/ 
Publications/The\%20Middle\%20of\%20the\%20Pyramid_The\%20Middle\%20of \%20the\%20Pyramid.pdf.

Beane, T. \& Ennis, D. 1987. Market segmentation: a review. European Journal of Marketing, 21(5):20-42. doi: 10.1108/EUM0000000004695.

Boumphrey, S. \& Bevis, E. 2013. Reaching the emerging middle classes beyond BRIC. Euromonitor International, 2013:1-44. http://go.euromonitor.com/rs/ euromonitorinternational/images/Reaching\%20the\%20Emerging\%20Middle\% 20Classes\%20Beyond\%20BRIC.pdf?mkt_tok=3RkMMJWWfF9wsRoivqzBZ KXonjHpfsX+7uwpWKa+lMI/0ER3fOvrPUfGjI4CTsZiI+SLDwEYGJlv6SgF QrDAMatv0bgKWhg\%3D.

Breazeale, M., \& Lueg, J. E. (2011). Retail shopping typology of American teens. Journal of Business Research, 64(6), 565-571. doi: 10.1016/j.jbusres.2010.06.007.

Broadbridge, A., and Eric Calderwood. 2002. "Rural Grocery shoppers: Do Their attitudes Reflect Their Actions?" international Journal of Retail \& Distribution Management 30(8) : 394-406

Brooks, C. 2011. Treating the poor like zoo animals. Globalpost. Accessed March 27. http://www.globalpost.com/dispatch/study-abroad/100911/south-africa-povertytours-tourism-townships?page $=3,0,0,3$.

Business Dictionary. 2012. Values, Attitudes and Lifestyles System (VALS-2). Accessed April 30. http://www.businessdictionary.com/definition/ValuesAttitudes-and-Lifestyles-System-VALS-2.html. 
Cai, Y. \& Shannon, R. 2011. Personal values and mall shopping behavior: The mediating role of attitude and intention among Chinese and Thai consumers. Australasian Marketing Journal, 20(2012):37-47. doi:10.1108/09590551211211783.

Consumer Scope. 2011. The 4 Lifestyle Levels. Accessed 26 July. http://www.Consumer Scope.cp.za/four_lifestyles.

Dawar, N. \& Chattopadhyay, A. 2002. Rethinking marketing programs for emerging markets. $\quad$ Long Range Planning, 35:457-474. doi:10.1016/S00246301(02)00108-5.

De Bruyn, P. \& Freathy, P. 2011. Retailing in post-apartheid South Africa: the strategic positioning of Boardmans. International Journal of Retail \& Distribution Management, 39(7):538-554. doi:10.1108/09590551111144914.

De Kock, H. L., Van Heerden, S. M., Heinze, P. H., Dijksterhuis, G. B., \& Minnaar, A. 2001. Reaction to boar odour by different South African consumer groups. Meat Science, 59(4), 353-362. doi: 10.1016/S0309-1740(01)00087-0.

Demacon. 2010. Impact of township shopping centres. Urban Landmark, July:34-38. http://www.urbanlandmark.org.za/downloads/retail_in_townships 2011_03.pdf.

Donaldson, R., Mehlomakhulu, T., Darkey, D., Dyssel, M., \& Siyongwana, P. 2013. Relocation: To be or not to be a black diamond in a South African township?. Habitat International, 39, 114-118. doi:10.1016/j.habitatint.2012.10.018 
Du Plessis, P.J. \& Rousseau, G.G. 2007. Buyer behaviour: understanding consumer psychology and marketing. 4th ed. South Africa: Oxford University Press.

Dunne, P.M. \& Lusch, R.F. 2008. Retailing. 6th ed. South-Western: Thomson Learning.

El-Adly, M. I. 2007. Shopping malls attractiveness: a segmentation approach. International Journal of Retail \& Distribution Management, 35(11):936-950. doi:10.1108/09590550710828245.

Farrag, D.A., Sayed, I.M \& Belk, R.W. 2010. Mall shopping motives and activities: A multi-method approach. Journal of International Consumer Marketing, 22:95115. doi:10.1080/08961530903476113.

Findley, L. \& Ogbu, L. 2001. South Africa: From Township to Town. Accessed July 30. http://places.designobserver.com/feature/south-africa-after-apartheid-fromtownship-to-town/31148/.

Goyal, M., 2010. South Africa: Rise of the black middle class. Forbes India Magazine, 18.

Haferburg, C., 2013. Townships of To-Morrow? Cosmo City and inclusive visions for post-apartheid urban futures. Habitat International, 39, pp.261-268.

Huchzermeyer, M. 2011. Cities with 'slums': from informal settlement eradication to a right to the city in Africa. University of Cape Town Press, Cape Town.

Jayasankaraprasad, C., \& Kathyayani, G. 2014. Cross-format shopping motives and shopper typologies for grocery shopping: a multivariate approach. The International Review of Retail, Distribution and Consumer Research, 24(1), 79115.doi:10.1080/09593969.2013.801358. 
Kaus, W. 2013. Conspicuous consumption and "race": Evidence from South Africa. Journal of Development Economics, 100(1), 63-73. doi:10.1016/j.jdeveco.2012.07.004.

Khare, A. 2011. Mall shopping behaviour of Indian small town consumers. Journal of Retailing and Consumer $\quad$ Services, $18: 110-118$. doi:10.1016/j.jretconser.2010.10.005.

Kunene, T. 2011. Interview with Dlamini P. Township markets. Sowetan. Accessed March 27. http://www.sowetanlive.co.za/news/business/2011/10/03/townshipmarkets.

Kuruvilla, S. J., \& Joshi, N. (2010). Influence of demographics, psychographics, shopping orientation, mall shopping attitude and purchase patterns on mall patronage in India. Journal of Retailing and Consumer Services, 17(4), 259-269. doi:10.1016/j.jretconser.2010.02.003.

Lesser, J. A., \& Hughes, M. A. 1986. Towards a typology of shoppers. Business Horizons, 29(6), 56-62.

Levy, M. \& Weitz, B. 2004. Retailing Management. 5thed. New York, NY: McGrawHill.

Ligthelm, A.A. 2003. Size, structure and profile of the informal retail sector in South Africa, Pretoria: Unisa, Bureau of Market Research. Research Report no 323. Unisa (University of South Africa).

Ligthelm, A.A. 2007. The impact of shopping mall development in township areas on small township retailers. Pretoria: Media release, Bureau for Market Research. 
Research Report no 359. Unisa (University of South Africa). http://reference.sabinet.co.za/sa_epublication_article/ecoman_v11_n1_a3.

Lustig, N., Lopez-Calva, L.F. \& Ortiz-Juarez, E, 2013. Declining Inequality in Latin America in the 2000s: The Cases of Argentina, Brazil, and Mexico, World Development, 44:129-141.

McGaffin, R. \& Gavera, L. 2011. Taking stock: the development of retail centres in emerging economy areas. Urban Landmark, (83p). Accessed April 7. http://www.urbanlandmark.org.za/downloads/retail_in_townships_booklet_2011 .pdf.

Miotto, A.P.S. and Parente, J., 2015. ANTECEDENTS AND CONSEQUENCES OF HOUSEHOLD FINANCIAL MANAGEMENT IN BRAZILIAN LOWERMIDDLE-CLASS. Revista de Administração de Empresas, 55(1), pp.50-64.

Morschett, D., Swoboda, B., \& Foscht, T. 2005. Perception of store attributes and overall attitude towards grocery retailers: the role of shopping motives. The International Review of Retail, Distribution and Consumer Research, 15(4), 423-447.doi:10.1080/09593960500197552.

Mortimer, G. 2013. Rolling in the aisles: a comparative study of male and female grocery shopper typologies. The International Review of Retail, Distribution and Consumer Research, 23(1), 1-30.doi:10.1080/09593969.2012.711255.

Moschis, G. 1992. Gerontographics: a scientific approach to analyzing and targeting the mature market. The Journal of Services Marketing, 6(3):1726.doi:10.1108/08876049210035890.

Mtongana, L. 2008. The changing face of SA's townships. SA Good News. http://www.sagoodnews.co.za/index2.php. 
Mukherjee, A. \& Satija, S. 2012. New middle class: Boao Review. Research on International Economic Relations. http://www.boaoreview.com/plus/view.php?aid=38.

Oxford, T. 2013. Is South Africa finally moving towards an efficient commuter infrastructure. Mail and Guardian, 4 October 2013.

Pettman, C.1913. Africanderisms; a glossary of South African colloquial words and phrases and of place and other names. Longmans, Green and Co. Accessed March 27. http://books.google.co.za/books/about/Africanderisms.html?id= O2sUA AAAIAAJ\&redir_esc=y.

Prinsloo, D. 2008. Retail trends - what does the future hold?. Urban Studies. Accessed March 24. http://www.urbanstudies.co.za/mar-shopping10.html.

Reynolds, K.E., Ganesh, J. and Luckett, M., 2002. Traditional malls vs. factory outlets: comparing shopper typologies and implications for retail strategy. Journal of Business Research, 55(9), pp.687-696.

Reynolds, F. \& Darden, W. 1972. Intermarket patronage: a psychographic study of consumer outshoppers. Journal of Marketing, 36(4):50-54. doi:10.2307/1250427.

Ruhiiga, T.M. 2011. The wholesale-retail sector and changes in consumer market response in rural South Africa. Journal of Social Science, 29(1):91-99. http://www.krepublishers.com/02-Journals/JSS/JSS-29-0-000-11-Web/JSS-291-000-2011-Abst-PDF/JSS-29-1-091-11-1318-Ruhiiga-T-M/JSS-29-1-091-111318-Ruhiiga-T-M-Tt.pdf.

Schiffman, L. \& Kanuk, L. 2007. Consumer Behaviour. 9thed. New Jersey: Pearson Prentice Hall. 
Sheth, J.N. 2011. Impact of emerging markets on marketing: rethinking existing perspectives and practices. Journal of Marketing, 75 (July):166-182. doi:10.1509/jmkg.75.4.166.

Shim, S. \& Eastlick, M.A.1998. The hierarchical influence of personal values on mall shopping attitude and behaviour. Journal of Retailing, 74(1):139-160. doi:10.1016/S0022-4359(99)80091-8.

Sibanyoni, M. 2012. New Soweto Mall. SowetanLive. Accessed June 25. http://www.sowetanlive.co.za/news/business/2012/10/02/new-soweto-mall.

Sit, J., Merrilees, B. \& Birch, D. 2003. Entertainment-seeking shopping centre patrons: the missing segments. International Journal of Retail and Distribution Management, 31(2):80-94. doi:10.1108/09590550310461985.

Sithole, A. 2011. Benefits from being a BRICS member: A lesson from India - the risk of the secession of the middle- and upper-classes. Strategy Insights Politics, 21(8):1-4.

South African Advertising Research Foundation. 2012. Living Standards Measure. Accessed March 27. www.saarf.co.za.

SouthAfrica.info. 2006a. SA youth better off than parents'. SouthAfrica.info. Accessed September 13. http://www.southafrica.info/about/people/youth130606.htm\#.VSPWE7dEipo.

SouthAfrica.info. 2006b. Township property market hots up. SouthAfrica.info. Accessed April 7. http://www.southafrica.info/business/investing/opportunities/ property-250106.htm\#.VSPWQLdEipo.

SouthAfrica.info. 2007. SA's booming Black middle class. SouthAfrica.info. Accessed March 27. http://www.southafrica.info/about/people/Blackdiamonds230507.html. 
SouthAfrica.info. 2013. SA's black middle class on the rise. SouthAfrica.info. Accessed August 23. http://www.southafrica.info/business/economy/middle-class300413.htm\#ixzz31sZxTMjC.

Stone, P.1954. City shoppers and urban identification: observations on the social psychology of city life. American Journal of Sociology, 60(1):36-45. http://www.jstor.org/stable/2772780.

Strydom, J.W. 2011. Retailing in disadvantaged communities: the outshopping phenomenon revisited. Journal of Contemporary Management, 8:150 - 172. http://reference.sabinet.co.za/sa_epublication_article/jcman_v8_a7.

Venkatesh, R. 2011. New parameters in market segmentation - ethnic marketing is the key. Advances in Management, 4(11):15-19. http://www.managein.net/bk_issue/abst_4_11.html.

Vermeulen, H., Kirsten, J. F., Doyer, T. O., \& Schönfeldt, H. C. 2005. Attitudes and acceptance of South African urban consumers towards genetically modified white maize. Agrekon, 44(1), 118-137. doi:10.1080/03031853.2005.9523705.

Visagie, J. 2013. Who are the middle class in South Africa? Does it matter?. Accessed March 18. http://www.econ3x3.org/article/who-are-middle-class-south-africadoes-it-matter-policy.

Visagie, J. \& Posel, D. 2013. A reconsideration of what and who is middle class in South Africa. Development Southern Africa 30(2):149-167. doi:10.1080/0376835X.2013.797224.

Wind, Y. 1978. Issues and advances in segmentation research. Journal of Marketing Research, 15, 317-337. doi:10.2307/3150580. 